\title{
Cretaceous stage boundaries - Proposals
}

\author{
T. BIRKELUND, J. M. HANCOCK, M. B. HART, P. F. RAWSON, J. REMANE, F. ROBASZYNSKI, F. \\ SCHMID and F. SURLYK
}

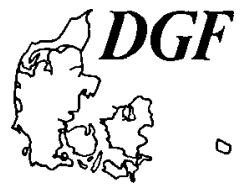

\begin{abstract}
Birkelund, T., Hancock, J. M., Hart, M. B., Rawson, P. F., Remane, J., Robaszynski, F., Schmid, F. and Surlyk, F.: Cretaceous Stage Boundaries - Proposals. Bull. geol. Soc. Denmark, vol. 33, pp. 3-20, Copenhagen, September, 10th, 1984. https://doi.org/10.37570/bgsd-1984-33-01
\end{abstract}

This paperis concerned with the chronostratigraphy of the Cretaceous System. It represents a compilation of the proposals that have resulted from the joint efforts of the three working groups of the Subcommission on Cretaceous Stratigraphy, as presented at the symposium in Copenhagen 1983. The workinggroups are those on: the Pre-Albian, the Albian-Turonian, and the Coniacian-Maastrichtian.

T. Birkelund, Institute of historical Geology and Palaeontology, Øster Voldgade 10, 1350 Copenhagen K, Denmark, J. M. Hancock, Department of Geology, King's College, Strand, London WC2R 2LS, U.K., M. B. Hart, Department of Environmental Sciences, Plymouth Polytechnic, Drake Circus, Plymouth PL4 $8 A A$, U.K., P. F. Rawson, Department of Geology, University College London, Gower Street, London WCIE 6BT, U.K., J. Remane, Université de Neuchâtel, Institut de Géologie, 11, rue E. Argand, 2000 Neuchâtel, Switzerland, F. Robaszynski, Faculté Polytechnique, Rue de Houdain, 9, 7000 Mons, Belgium, F. Schmid, Niedersächsisches Landesamt für Bodenforschung, Postfach 510153, 3000 Hannover 51, BRD, F. Surlyk, Grønlands geologiske Unders $\emptyset$ gelse, Øster Voldgade 10, 1350 Copenhagen K, Denmark, May 10th, 1984.

\section{Cretaceous series and stages}

A unified scale of Cretaceous stages has been generally accepted for a long time. However, the earliest stage, the Berriasian, is often replaced by the Ryazanian, reflecting the particular difficulties of correlating between the Tethyan and the Boreal Realms around the Jurassic-Cretaceous boundary.

A twofold division of the Cretaceous into a Lower and an Upper Series is generally accepted, the 'mid-Cretaceous' being an informal unit. There has been much confusion, however, as to how much of the Cretaceous should be included in the Neocomian and Senonian sub-Series.

The Subcommission supports the division of the Cretaceous into stages as shown in the table below and does not recommend the formalization of the Neocomian and Senonian.
Series Stages

\begin{tabular}{ll}
\hline & Maastrichtian \\
& Campanian \\
Santonian \\
Coniacian \\
Turonian \\
Cenomanian \\
\hline \\
& Albian \\
\hline \multirow{4}{*}{ Lower } & Aptian \\
& Barremian \\
& Hauterivian \\
& Valanginian \\
& Berriasian \\
\hline
\end{tabular}

Radiometric time scales (Lanphere \& Jones 1978, Odin 1982) show that the time span of the stages varies widely (up to $1: 10$ ). Formal definition of substage boundaries is therefore most useful within stages of very long duration.

It is recommended only to use the prefixes Lower and Upper or Lower, Middle and Upper for these substages so as to avoid introduction of new substage names. 


\section{Principles of defining the stages}

Cretaceous stages - like those of most other systems - originally were established on the basis of relatively uniform bodies of strata, the boundaries of which reflected some sorts of physical events, usually outlined by unconformities. As first introduced, they were defined neither as precisely nor as satisfactorily as modern needs demand.

Both the theoretical and the practical problems concerned with revisions of the definitions were discussed at length at the symposium. The following principles form a basis for the proposals.

The requirement of contiguity of a chronostratigraphic scale can best be met by defining only the lower boundary of each unit. The upper boundary is then formed by the lower boundary of the next succeeding unit. This procedure was not followed in the International Stratigraphic Guide (Hedberg 1976) although it has been recommended repeatedly by Callomon \& Donovan (e.g. 1966, 1974). It has also been accepted in the British Guide to Stratigraphical Procedure for a long time (most recently in Holland et al. 1978) and is now also accepted in the North American Stratigraphic Code (1982).

In order to achieve a modern revision of the stages it is usually necessary to seek the ideal boundary stratotype outside the original type area. It is strongly recommended to seek the level as close to common usage as possible. The bases of the majority of Cretaceous stages are characterized by hiati in the type areas. Whenever possible, definition within these breaks is to be recommended.

Agreement over the choice of horizons for the boundaries has to be obtained before decision on the physical boundary stratotype is possible. These two points are therefore kept apart in the proposals.

\section{Boundary markers}

The ideal boundary of a chronostratigraphic unit is characterized by a widely traceable isochronous marker. Up to now the best approximation to markers of that sort has been given by fossils, occasionally supported by magnetostratigraphy. Physical changes, as for example global falls in sea-level or oxic-anoxic events, clearly influenced the fossil record. By use of certain characteristic palaeontological events these physical changes may influence the definitions indirectly, but direct use of most physical changes should be avoided because of lack of precision.

It was agreed at the symposium that stages are "packages of zones" and that the most sensible way to define a stage is by the base of the earliest biozone at a boundary stratotype. In this connection it is worth emphazising that the stage concept as defined in the International Stratigraphic Guide (Hedberg 1976) was not supported. The base of the zone should preferably be defined on the first appearance of a new taxon. Ideally, the taxon to be chosen should be widespread, reasonably common, and identifiable by the non-specialist. Taxa belonging to well known phylogenetic series are preferable.

Provincialism is the most serious obstacle to the regional correlation by fossils. Basin-wide biostratigraphical scales (local 'standard scales') are therefore the cornerstone in regional correlation, the first necessary step before inter-provincial correlation can be accomplished.

Correlation to Tethyan and Boreal Realms of most Cretaceous stages is particularly difficult. Neither macrofossils like ammonites or inoceramids, nor planktonic foraminifera or nannofossils, are generally sufficiently cosmopolitan to serve as index fossils in both realms. The heterochronous first appearance of a number of important taxa is also a problem.

As a result of provincialism, long distance correlation usually depends on indirect fossil evidence: definition on the basis of one index taxon needs to be supported by other palaeontological events in order to fulfil regional correlation.

A number of participants especially among micropalaeontologists, stressed the importance of extinction events of certain planktonic foraminifera for long-distance correlation. Some of these events can be related to sea-level changes (Hart 1980, Caron \& Homewood 1983). Extinction events within other groups were also considered. However, it was agreed by most participants that appearance of new taxa must be the prime tool for definition, while extinction events (if well defined in relation to the boundary) are extremely important in actual practise. 


\section{Boundary stratotypes}

Important geological requirements of a boundary stratotype are continuous sedimentation, no facies change across the boundary and high faunal diversity. Ease of access, and permanence should also be considered.

Because of provincialism the geographical location is crucial. Areas showing overlap of faunal provinces have the best potential for fulfilling the correlation requirements.

In a number of cases, boundary stratotypes were proposed in very poorly known sections in the Tethyan Realm, hoping for the chance of solving stratigraphic problems not solved in thoroughly described sections in the Boreal Realm. Careful planning of work on these sections is necessary if the Subcommission is to be able to make final proposals in the near future on the Cretaceous Stage boundaries.

\section{Berriasian-Valanginian Boundary}

\section{The Valanginian Stage}

Author: Desor (1854); first description of the type succession by Desor \& Gressly (1859).

Type area: The Seyon Gorge in the Jura Mountains, near Valangin (Canton Neuchâtel, Switzerland). The historical Valanginian with some hesitation was defined as beginning with the first marine sediments overlying the Purbeckian facies of the Jura Mountains (Desor \& Gressly 1859). Ostracode correlation indicates that this "Purbeckien" corresponds to the Lower and lower Middle Purbeck Beds of England. The first ammonites, among them Saynoceras verrucosum, appear only high up in the type sequence; here, forms older than Late Valanginian are reworked. Under these conditions, it is impossible to determine the exact position of the Berriasian-Valanginian boundary, as defined in Mediterranean cephalopod facies, within the succession of the type area. An important part of the historical type Valanginian has now to be assigned to the Berriasian.

Hypostratotypes of the Valanginian in its current sense have been proposed by Busnardo et al. (1979) in the Mediterranean cephalopod facies of southeast France (Vocontian Basin) at Barretle-Bas (Hautes-Alpes) and Angles (Alpes-de-
Haute-Provence) (see Rawson 1983). Together with ammonites, the stratigraphic distribution of belemnites, ostracodes, calpionellids, foraminifera and nannofossils was studied in detail in these two sections.

Possible boundary levels

Ammonites

a) In southeast France the boundary is currently placed at the base of the Thurmanniceras otopeta Zone. The underlying Berriasella callisto Subzone of the Fauriella boissieri Zone forms the top of the Berriasian (Le Hégarat \& Remane 1968; Le Hégarat 1973).

b) Hoedemaeker $(1982,1983)$ described a fauna from southeast Spain that combines elements of both the $B$. callisto Subzone and the $T$. otopeta Zone. This fauna has not been recognized in France, but the horizon in question at some localities shows evidence of a hiatus, or ammonites are rare or absent. Hoedemaeker (1982, 1983) proposed the Tirnovella alpillensis Subzone for this horizon, and he correlated the base of this subzone with the base of the French $B$. callisto Subzone.

Hoedemaeker placed his T. alpillensis Subzone in the Valanginian because several species which are characteristic of the French T. otopeta Zone (N. premolicus, T. thurmanni, and T. gratianopolensis) appear at the base of the preceding subzone in southeast Spain.

At the symposium in Copenhagen it was suggested that the name $B$. callisto Subzone should be used for the T. alpillensis Subzone in Spain because there are species in common between the two areas and because the subzonal bases were supposed by Hoedemaeker to coincide on the basis of calpionellid evidence. Since then Hoedemaeker (this volume) has revised his original definition and now correlates his $T$. alpillensis Subzone with the thicker upper part of the $B$. callisto Subzone. He correlates the lower part of the $B$. callisto Subzone in the Berriasian type area with the uppermost part of his Berriasella picteti Subzone in Spain. He retains the Berriasian-Valanginian boundary at the base of the $T$. alpillensis Subzone. 
Other groups

Calpionellids

The Berriasian-Valanginian boundary, placed at the base of the $T$. otopeta Zone, is situated in the uppermost part of the Calpionellopsis Zone in terms of Rome Standard Zones (Allemann et al. 1971), or within Subzone D3 in terms of Vocontian calpionellid zones (Le Hégarat \& Remane 1968). The boundary thus lies between the first appearance of Lorenziella hungarica ( $=$ base of D3) and the first appearance of Calpionellites darderi ( $=$ base of Zone $\mathrm{E}=$ Calpionellites Standard Zone). The base of Hoedemaeker's $T$. alpillensis Subzone corresponds either to the base of D3 or to a slightly higher level, depending which definition will finally be adopted. As a matter of fact, the exact correlation between Spanish and French ammonite associations relies rather on calpionellid faunas than on ammonites themselves (Hoedemaeker 1983 and in the discussion at Copenhagen). It might then seem more logical to define the boundary directly by calpionellids (instead of ammonites correlated by calpionellids).

\section{Nannofossils}

At the French hypostratotypes, Calcicalathina oblongata appears in the Thurmanniceras pertransiens Zone, which overlies the $T$. otopeta Zone. The first occurrence of Nannoconus bermudezi and $N$. kamptneri may be close to the two ammonite boundaries mentioned above (see Perch-Nielsen 1983). Further work is needed to determine the exact levels in relation to the ammonite zonation.

Foraminifera

According to Moullade (in Busnardo et al. 1979) the Berriasian-Valanginian boundary is difficult to characterize by benthic foraminifera. Lenticulina nodosa nodosa (Reuss) sensu Bartenstein (1974) is the only species whose first occurrence is very close to the base of the $T$. otopeta Zone.

\section{Conclusion}

Boundary level: At the symposium both the base of the T. otopeta Zone and the base of the $B$. callisto Subzone were considered, as it seemed that the calpionellid correlation supported that of Hoedemaeker.

However, because of the uncertainties arising from Hoedemaeker's revised correlation we conclude that for the present it is recommended that the boundary should still be at the base of the $T$. otopeta Zone.

A final decision depends on the discussion on the Jurassic-Cretaceous boundary. If this boundary is raised and the base of the Valanginian lowered, the remaining Berriasian would be so small that this stage would hardly be worth retaining.

Boundary stratotype: Candidates should be investigated in southeast Spain, southeast France, the Crimea and Caucasus depending on the final choice of level.

Regional correlation: Platylenticeras occurs in both north Germany (Boreal Realm) and southeast France (Tethys). Forms comparable with the earliest German species first appear in the upper part of the T. otopeta Zone in France (Kemper, Rawson \& Thieuloy 1981), but they are very rare. There was little faunal mixing between the two realms at this time, but for the Valanginian to Barremian Stages the sections in the Crimea and Caucasus may provide the best clues for correlation as they were areas of marked faunal mixing.

\section{Valanginian-Hauterivian Boundary}

The Hauterivian Stage

Author: Renevier (1874)

Type area: "Hauterive" in Neuchâtel, Switzerland (see Rawson 1983).

Possible boundary levels

Ammonites

a) The base of the Hauterivian is currently defined by the first appearance of Acanthodiscus radiatus and allied species. The value of Acanthodiscus lies in its occurrence in shallow water facies of both the Tethyan and Boreal Realms.

The use of this species as a zonal index in Tethyan areas has been criticized because of its rarity in deep-water facies. It may prove necessary to re-zone the top Valanginian and basal Hauterivian strata of the western Mediterranean areas eventually, but this should not preclude using the first appearance of Acanthodiscus to 
mark the base of the Hauterivian Stage, even if the first appearance falls within another ammonite zone.

b) In Tunisia Acanthodiscus radiatus is not known and Memmi (1981, p. 177-178) defined the basal zone of the Hauterivian there by the first occurrence of Breistrofferella castellanensis.

c) In the abstracts for the Copenhagen symposium and in this volume, Hoedemaeker has proposed that the base of the Hauterivian be drawn at the base of the Himantoceras trinodosum Zone following Busnardo (In Debelmas \& Thieuloy 1965). This level is currently placed within the Upper Valanginian. His main argument is that there is a major faunal turnover at this level, corresponding with a fall in sea-level.

\section{Other groups}

Among coccoliths the first occurences of Chiastozygus striatus and Cretarhabdus loriei have been used for defining the ValanginianHauterivian boundary, and among Nannoconus the first occurrence of $N$. minutus and $N$. bucheri.

In the Boreal Realm the detailed work on foraminifera of Fletcher (1973) and Hart et al. (1981) has recognized several important faunal changes at, or about, this level. Appearing at this level are such distinctive species as Epistomina ornata (Roemer), Lenticulina ouchensis wisselmanni Bettenstaedt, Citharina harpa (Roemer) and Citharina sparsicostata (Reuss), all of which were used by Bartenstein (1977) in his Lower Cretaceous zonation.

\section{Conclusion}

Boundary level: Definition of the boundary on the basis of the first occurrence of the ammonite genus Acanthodiscus is recommended (Acanthodiscus radiatus and allied species). By tradition the boundary has been placed at this level for more than eighty years.

We disagree with Hoedemaeker's choice of level at the base of the Himantoceras trinodosum Zone and the reasons behind his suggestion, as discussed in the introduction. If the boundary were to be radically altered, the base of the Saynoceras verrucosum Zone would be a better marker. This currently marks the base of the Upper Valanginian!
Boundary stratotype: Sections should be investigated in southeast France, southeast Spain, the Crimea and Caucasus. However, it should be noted that Thieuloy (1977, p. 125) proposed the base of the $A$. radiatus Zone at La Charce (Drôme) as a boundary stratotype.

Regional correlation: The appearance of Acanthodiscus can be widely traced in shallow water facies in both the Tethyan and the Boreal Realms (northwest Europe). It is rare in Tethyan deepwater facies.

\section{Hauterivian-Barremian Boundary}

The Barremian Stage

Author: Coquand (1861)

Type area: Angles, Basses-Alpes, France (designated by Busnardo 1965; see Rawson 1983).

Possible boundary levels

Ammonites

From the southeast of France and from Tunisia through the Carpathians to the Crimea and Caucasus there occur distinct beds with Pseudothurmannia, overlain by beds with the first Holcodiscus ( $H$. caillaudianus group).

The Hauterivian-Barremian boundary has been placed at three different levels in relation to these beds:

a) Currently, Busnardo (in Rawson 1983, p. 498) defines the base of the French Barremian by the first appearance of Barremites and Raspailiceras high in the Pseudothurmannia beds. The lower Pseudothurmannia beds are placed in the Hauterivian Zone of $P$. angulicostata (though the zonal index is poorly known and may be a younger, early Barremian, form).

b) In Czechoslovakia (Vašíček et al. 1983) and Bulgaria (Avram 1983) the base of the Barremian is placed at the base of the Pseudothurmannia beds.

c) In the Crimea and Caucasus (Kakabadze 1983) the boundary is placed at the top of the Pseudothurmannia beds (i.e. base of the Holcodiscus beds).

Other groups

First occurrences of species of Nannoconus (abundans, borealis, grandis, elongatus, wassallii) 
may help to define the boundary, when determined stratigraphically in relation to the ammonite zonation.

In the Boreal Realm no new foraminiferal taxa appear at the base of the Barremian although some distinctive Hauterivian taxa (Epistomina ornata, Lenticulina ouchensis wisselmanni, Lenticulina guttata (Ten Dam)) become extinct.

\section{Conclusions}

Boundary level: The consensus at the Copenhagen symposium was that there are two good candidates for the stage boundary:

1) The base of the Pseudothurmannia beds, or 2) the top of the Pseudothurmannia beds (i.e. base of the Holcodiscus beds). A boundary within the Pseudothurmannia beds should be avoided.

Boundary stratotype: Sections in southeast France, southeast Spain, the Carpathians, the Crimea and the Caucasus should be considered.

Regional correlation: Both the proposed ammonite levels can be widely traced in the Tethyan Realm. Correlation with the Boreal Realm is more difficult. In north Germany and eastern England the fauna consists almost exclusively of heteromorphs, most of which have been placed in different species or even genera from Tethyan ones (e.g. Immel 1978). The differences may reflect simply the preservation of different growth stages (Kemper, Rawson \& Thieuloy 1981). Further investigations may show that species of the Crioceratites (Paracrioceras) emerici group are good inter-regional markers.

\section{Barremian-Aptian Boundary}

The Aptian stage

Author: d'Orbigny (1840).

Type area: Apt (Vaucluse) in southeast France. La Bedoule, Gargas (near Apt) and Clansayes are all reference sections for subdivisions of the Aptian though not all are satisfactory for correlation purposes (see Rawson 1983).

Possible boundary levels

Ammonites

The first appearance of Prodeshayesites is taken to mark the base of the Aptian in both northwest Europe (England and Germany) and southeast France.

\section{Other groups}

First occurrences of the coccoliths Chiastozygus platyrhetus and Rucinolithus irregularis may characterize the same level.

No distinctive foraminiferal change at the base of the Aptian has been demonstrated in the Boreal Realm. In Tethyan areas early in the Early Aptian there is the appearance of the Praeorbitolina lineage. According to Salaj (1980) Planomalina (Globigerinelloides) ferreolensis appears at the base of the Deshayesites deshayesi Zone in Tunisia.

\section{Conclusion}

Boundary level: It is recommended that the base of the Aptian should continue to be placed at the first appearance of Prodeshayesites.

Boundary stratotype: Sections in southeast France, Turkmenya (as recommended by Bogdanova et al. in the Copenhagen abstract volume), England and north Germany should be considered.

Regional correlation: There was less faunal differentiation across Europe during the Aptian than during earlier periods, though the proportion of Tethyan genera increases southwards. The French ammonite sequence is inadequately documented (see Moullade et al. 1980), but Prodeshayesites occurs there with more typically Tethyan genera and thus provides a link between Boreal and Tethyan faunas. Deshayesites first appears above the first Prodeshayesites but may be more widespread geographically. However, there is dispute as to whether the Venezuelan faunas, for example, really belong to this genus.

\section{Aptian-Albian Boundary}

The Albian Stage

Author: d'Orbigny (1842-43).

Type area: Aube in the Paris Basin. The earliest well-dated Albian in the area is a phosphatic bed containing Leymeriella tardefurcata and Hypacanthoplites aff. milletianus, overlying twenty 
metres of "sables verts" (clayish glauconitic sands) lacking age-diagnostic fossils. "Argiles à Plicatules" below the "sables verts" is Lower Aptian. Except for the probable gap between the Aptian and Albian, the Albian is well developed in the area (see Magniez-Jannin 1975; Rat et al. 1980; Robaszynski, this volume).

\section{Possible boundary levels}

\section{Ammonites}

a) Since Breistroffer (1947) the conventional base of the Albian has been drawn at the appearance of the lineage of the Leymeriellidae as represented by Leymeriella ('Proleymeriella') schrammeni anterior (see Owen, this volume).

Initially Leymeriella appears to have been endemic to the Albian North Atlantic (including north Germany and East Greenland) but it spread later to eastern and southern Europe. On the basis of Hypacanthoplites species occurring in England as well as northern Germany, the English Farnhamia farnhamensis Subzone was correlated with the Leymeriella schrammeni Zone by Casey (1954).

b) Because of the geographically restricted occurrence of early leymeriellids, the possibility of elevating the base of the Albian to the appearance of Douvilleiceras s.s. was discussed.

Douvilleiceras is widespread in Europe and also in the Tethyan Realm. It appears first in the Leymeriella regularis Subzone of the L. tardefurcata Zone, below the best known zone of the genus, that of Douvilleiceras mammilatum. Such pre-mammilatum Zone occurrences seem to be rare and $D$. mammilatum itself is limited, at least in Britain, to its own zone (Casey 1960, p. 270).

Unfortunately, species of Douvilleiceras are not sufficiently distinctive to provide a precise base for the stage which can be recognized easily over a wide area. Because of the presence of Douvilleiceras, it has been assumed that sediments containing this genus in a number of areas in the Gondwanan province are of Early Albian, D. mammilatum Zone age, but they can in a number of instances be shown to be of early Middle Albian Age (see Owen, this volume). A firm definition would depend on finds of continuous successions of the Eudouvilleiceras-Douvilleicéras stock (possibly in the northern part of South America).

\section{Other groups}

It was also suggested that the first occurrence of the coccolith Prediscosphaera columnata could be used, but it was not clear how this compared with the ammonite sequence. In the Aube area it appears in the Otohoplites ravlinianus Zone. No distinctive foraminiferal change at the base of the Albian has been found.

\section{Conclusion}

Boundary level: It is recommended at present to retain the base of the Albian at the base of the $L$. schrammeni Subzone in the well documented European succession and to investigate all possibilities of correlation with regions outside Europe. In this connection determination of the appearance of Prediscosphaera columnata in relation to the apperance of $L$. schrammeni is important.

Boundary stratotype: The basal Albian is missing in the type-area. Owen $(1979$, p. 569$)$ has recommended that a horizon, the junction of Beds $6 \mathrm{a}$ and $6 \mathrm{~b}$ in a measured section of clays spanning the uppermost Aptian and lowest Albian exposed near Vörhum in the Hannover-Braunschweig area of north Germany, be taken as the formal boundary stratotype (see also Owen, this volume). A better choice is hardly possible if the base of the L. schrammeni Subzone is chosen as the boundary level.

Regional correlation: Within great parts of Europe, the lowest Lower Albian is either not represented, or is subject to minor ammonite provincialism, and a major sedimentary hiatus affects Aptian-Albian boundary layers throughout much of the Tethyan Realm (see Owen, this volume). Occurrences of forms of early Leymeriella together with the Arctic genus Freboldiceras in North Greenland has largely solved the problem of correlation of the earliest Albian of the European province with the Arctic and northern $\mathrm{Pa}$ cific provinces (Birkelund \& Håkansson 1983; Owen, this volume).

\section{Albian Substages}

In view of the great length of the Albian (12 m.y. on the scale given by Odin at the symposium) definitions for the base of the Middle and Upper Albian were considered. 
Base of the Middle Albian: It was agreed to use the base of the Subzone of Lyelliceras lyelli. The best sequences across the boundary are situated in the classic region of the Aube, where it is recommended that a substage boundary stratotype be defined (see Owen 1971; Destombes 1979). The $L$. lyelli Subzone can be recognized in both the hoplitinid and brancoceratid faunal provinces, but it is difficult to correlate with the Arctic province (see Owen, in press and this volume).

Base of the Upper Albian: It was agreed to use the base of the zone of Dipoloceras cristatum. In the Boreal Realm this level also appears to be marked by the appearance of Arenobulimina chapmani Cushman (Magniez-Jannin 1975; Carter \& Hart 1977; Hart 1973). Owen (this volume) proposes a section at Folkestone, Kent, as the boundary stratotype. This area has the disadvantage that the $D$. cristatum Zone may be in a condensed bed containing phosphatic nodules. However, this condensation is not extensive and both at Folkestone and in borings nearby, the earliest $D$. cristatum Subzone is present (see Owen, this volume). The classical and wellknown section at Wissant (France), recently investigated for its microfossil content (Amedro \& Magniez-Jannin 1982), is also a possibility. Another choice could be in north Texas where an extensive Middler-Upper Albian ammonite fauna is known. This includes both Dipoloceras cristatum and mortoniceratids and mojsisovicziinids of Tethyan regions. The few specimens of $D$. cristatum came from the top part of the Goodland Limestone north-west of Forth Worth in Tarrant County (Young \& Powell 1978).

\section{Albian-Cenomanian Boundary}

\section{The Cenomanian Stage}

Author: d'Orbigny (1847)

Type area: Le Mans (Sarthe) in the Paris Basin (see Juignet 1977; 1980; Kennedy this volume and Juignet et al., in press).

On the basis of foraminifera it seems that in the Sarthe area, there is a transitional passage between the Upper Albian (base of "Argile glauconieuse à minerai de fer", "Glauconie à $O$. vesicularis") and the Lower Cenomanian ("Mar- nes de Ballon", "Craie glauconieuse à Pecten asper") (Robaszynski, this volume; Juignet et al., in press), but at present no good exposures are available. Besides, ammonites, planktonic foraminifera and calcareous nannoplankton are not well represented by their zonal index species.

Possible boundary levels

Ammonites

The Albian-Cenomanian boundary is conventionally taken at the base of the widely recorded Mantelliceras mantelli Zone.

The exact position of the boundary is hampered by provincialism and insufficient knowledge on the stratigraphy of the Tethyan genus Graysonites, characterizing the interval between the highest mortoniceratids (i.e. typical Albian) and below the lowest Mantelliceras s.s. (see Hancock, this volume).

A number of different possibilities were discussed:

a) At the base of the Hypoturrilites schneegansi Zone. The zone was established by Dubourdieu (1956) on the basis of sections in Algeria and Tunisia. The bottom horizon is characterized by the appearance of $H$. schneegansi and a number of other taxa, but does not include Mantelliceras saxbii (= M. martimpreyi auct.) (see Hancock, this volume). Occasional Graysonites have been found, but their exact stratigraphical position is not known.

b) At the base of the Graysonites adkinsi Zone, defined by the first occurrence of G. adkinsi. The zone is defined in Texas (see Mancini 1979). Apart from additional Graysonites, the other ammonites are endemic species. Graysonites, on the other hand, is widely distributed in Tethyan and Pacific areas.

c) The base of the conventional basal zone of the Cenomanian in northern Europe, the Neostlingoceras carcitanense Zone, was also discussed. At the symposium W. J. Kennedy suggested that $H$. schneegansi was a synonym of $N$. carcitanense. This is rejected by Hancock (this volume). It was agreed that it would be inappropriate to define the boundary in the Boreal Realm because of the widespread break between Albian and Cenomanian in many areas.

d) The base of the Mariella (Wintonia) brazoensis Zone, underlying the Graysonites adkinsi Zone in Texas, was also mentioned. The zone is 
placed above the highest mortoniceratids, but the index species ranges downwards to overlap with mortoniceratids (Young 1957). This zone cannot be recognized outside Texas, and a boundary at its base was therefore not recommended.

e) For the same reason a boundary section in the Transdanubian Central Range in Hungary did not receive much support. The boundary is found in the Pénzeskut Marl, which is nearly $500 \mathrm{~m}$ thick, and ranges from low in the Upper Albian to the Middle Cenomanian. It has yielded a diverse fauna including more than 1000 ammonites spread over 49 genera and 62 species. However, the section belongs to the Boreal faunal province, in that it yields Hyphoplites, but apparently lacks Neostlingoceras, Idiohamites and Graysonites. The boundary would have to be defined on the appearance of a particular species of Hyphoplites, which was regarded as unsuitable.

\section{Other groups}

The characteristic extinction event of the planktonic foraminifera Planomalina buxtorfi happens slightly earlier than the appearance of Hypoturrilites schneegansi. Planomalina buxtorfi has now been described from the Gault Clay of Folkestone, immediately below the base of the Glauconitic Marl, the lithostratigraphical base of the "Cenomanian" in southeast England. This occurrence is coincident with a flood occurrence of the small, distinctive, planktonic foraminiferid Globigerinelloides bentonensis (Morrow), which in turn is used at the Albian-Cenomanian boundary marker over the whole of the North Sea Basin. There are several distinctive benthonic foraminiferal changes at this level, as documented by Carter \& Hart (1977) and Hart et al. (1981).

In Tethyan shelf carbonate successions the foraminiferal genus Orbitolina is very useful. Currently the appearance of Orbitolina (Orbitolina) concava concava and Orbitolina (Conicorbitolina) conica are used at this level.

Keeled rotaliporid foraminifera such as $R o$ talipora appeninica appear $2 \mathrm{~m}$ below Graysonites adkinsi in Texas (Mancini 1979).

The first occurrence of the coccolith Eiffellithus turriseiffeli slightly below the base of $\boldsymbol{H}$. schneegansi can be traced both in the Tethyan and the Boreal Realms.

\section{Conclusion}

Boundary level: It is recommended to investigate further a definition based on the first occurrence of Hypoturrilites, e.g. H. schneegansi. The genus Hypoturrilites can be used as a basis for correlation through North Africa, and is also known from the basal Cenomanian in Sarthe, France (Hancock 1960).

As a second choice, the first occurrence of Graysonites adkinsi was considered. The stratigraphical occurrence is well defined in Texas (see Hancock, this volume), and the genus is distributed in Mexico, Brazil, California, Japan, Spain and North Africa.

The two events are not yet correlated. Characteristic events within coccoliths and planktonic foraminifera occur close to both of them.

Boundary stratotype: 1) If $H$. schneegansi is chosen, a boundary stratotype in western central Tunisia or eastern Algeria (e.g. Monts du Mellègue) may be a possibility. An expanded, easily accessible section yields ammonites, planktonic foraminifera and nannofossils of pandemic occurrence (Boreal and Tethyan Realms).

2) If Graysonites adkinsi is chosen, a boundary stratotype near Grayson's Bluff, Denton County north of Fort Worth or White Rock Creek, west of Aquilla, Hill County (Mancini 1977, 1979) may be recommended (see Hancock, this volume).

3) A proposal on the designation of a stratotype in the Transdanubian Central Range, Hungary was also put forward.

\section{Cenomanian-Turonian Boundary}

\section{The Turonian Stage}

Author: d'Orbigny (1842).

Type area: Touraine, between Saumur (on the Loire) and Montrichard (on the Cher) (d'Orbigny 1842). (See Alcaydé 1980; Robaszynski, coord. 1982; Robaszynski et al. 1983; Kennedy, this volume).

Questions concerning the Cenomanian-Turonian boundary have been difficult to settle because of widespread condensation and breaks in sedimentation around this level in western Europe, including the type area. There is also an 
important anoxic event (Plenus Marls or equivalents) around this level that modifies facies; and provincialism is also marked.

Possible boundary levels

Ammonites

Extensive work both in Europe and North America over the last decade has shown the presence of a number of ammonite zones between the classical Mammites nodosoides Zone of the Turonian and the Metoicoceras geslinianum Zone of the Cenomanian (see Cobban, this volume; Hancock, this volume; and Kennedy, this volume).

On the basis of ammonites the following boundaries were discussed:

a) At the base of the Zone of Metoicoceras geslinianum (or the slightly later appearance of Euomphaloceras septemseriatum). One or both of these species can be found in Texas, Mexico, California, Angola, Nigeria, Columbia, Brazil and Japan.

b) The base of the Pseudaspidoceras flexuosum Zone. The zone was first recognized in northern Chihuahua, Mexico and nearby in the far west of Texas where it contains a variety of ammonites. It is now known to extend northwestwards into New Mexico - Arizona (see Cobban, this volume) and possibly into California. Instead of using the zonal index $P$. flexuosum, it may be better to use the appearance of a vascoceratid, possibly Vascoceras proprium. Correlation with vascoceratids can be extended to South America, West and North Africa. From these regions it should then be possible to extend correlation to Madagascar, Japan and Boreal Europe.

c) The appearance of the Assemblage Zone of Watinoceras coloradoense is the definition that has been most used by ammonite workers in Europe during the last few years. This level is close to proposal b) above. However, the nominate subspecies is absent in Europe, and the base of the zone is drawn at a lower level than the base of the zone of the same name in USA (see Cobban, this volume), this lower level probably corresponding to the base of the $P$. flexuosum Zone.

\section{Other groups}

d) Definition on the basis of the Mytiloides lineage. Both in Japan and in North America, early forms of that lineage appear in the Euompha- loceras septemseriatum Zone (Matsumoto, pers. comm. 1984; Kauffman et al. 1977). The base of the $P$. flexuosum Zone of North America is characterized by the appearance of Mytiloides opalensis sensu Kauffman non Böse. A widespread flood of Mytiloides may be correlated with the base of the P. flexuosum Zone, but synchroneity has not been proved.

e) The appearance of a flood of Mytiloides at the base of the assemblage zone of Mammites nodosoides was also considered.

f) Appearance of the coccolith Quadrum gartneri in the ammonite zone of Neocardioceras juddii is a widely recognizable event.

g) The extinction of the planktonic foraminifer genus Rotalipora is a widespread event in the Metoicoceras geslinianum Zone, and it is strongly recommended by Marks (this volume) that the boundary be made to coincide with this level. The extinction of Rotalipora cushmani (Morrow) follows immediately above that of $R$. greenhornensis (Morrow). Associated with the disappearance of the latter, there is a very significant faunal change, with the bulk of the benthonic foraminiferal fauna becoming extinct, see Jefferies (1962), Carter \& Hart (1977).

h) The appearance of Whiteinella archaecretacea in the middle of the same zone is also an important marker. The distinctive anoxic event of Schlanger \& Jenkyns (1976) has recently been shown (Hart \& Bigg 1981) to fall within the $W$. archaeocretacea Zone. This conclusion comes from successions in northeast England (Humberside); the so-called Black Band.

i) The appearance of the distinctive Turonian planktonic foraminifera, Praeglobotruncana helvetica (Bolli), occurs slightly above all the levels under discussion. Unfortunately its first appearance up-succession is probably facies/temperature controlled, and complicated by the presence of the "praehelvetica" form.

\section{Conclusion}

Boundary level: The boundary at the base of the Pseudaspidoceras flexuosum gained some support. In the present volume it is recommended in papers by Cobban and by Kennedy. However, $P$. flexuosum has a restricted geographical distribution.

Important support for that boundary is the widespread appearance of early Mytiloides as 
represented by $M$. opalensis sensu Kauffman at the same level, an event which can be traced in both Tethyan and Boreal regions (recommended by Hancock, this volume).

The appearance of Quadrum gartneri immediately below, in the Neocardioceras juddii Zone and the extinction of Rotalipora in the Metoicoceras geslinianum Zone further below are world-wide markers.

Boundary stratotype: If defined at the base of the $P$. flexuosum Zone (see Hancock, this volume) a section in Texas or Mexico, where both the Pseudaspidoceras flexuosum Zone and the underlying Neocardioceras juddii Zone are rich in ammonites, should be chosen. The presence of $M y$ tiloides and some other groups such as planktonic foraminifera is also crucial.

\section{Turonian-Coniacian Boundary}

The Coniacian Stage

Author: Coquand $(1856,1857,1858)$.

Type area: Environs of Cognac, Charente (see Séronie-Vivien 1980).

Kennedy (this volume) claims that careful reading of Coquand shows that the type locality is in the grounds of the seminary at Richemont. Both here and elsewhere in the area the Turonian limestones are separated from basal Coniacian deposits by a prominent discontinuity surface (Kennedy, this volume; Jarvis et al. 1982).

Possible boundary levels

Ammonites

a) The base of the Coniacian has conventionally been placed at the base of the Barroisiceras haberfellneri Zone. B. haberfellneri of authors recorded from Charente (Grossouvre 1894 to Séronie-Vivien 1972) belongs to Forresteria (Harleites) petrocoriensis (Coquand) (Kennedy, this volume). The appearance of this species is proposed as defining the boundary level by ammonite specialists.

Forresteria petrocoriensis s.s. is well represented in the environs of the type area and elsewhere in France (including the Craie de Villedieu of Touraine), and it also occurs in Czechoslovakia, Roumania, Spain, and Japan (see Matsumoto, this volume), and possibly also in
Germany. Closely allied taxa occur widely in the Soviet Union, Asia, Africa and South America.

\section{Other groups}

b) The first occurrence of Inoceramus (Cremnoceramus) deformis Meek and/or $I$. (C.) schloenbachi (Böhm) (see Tröger 1981; Bailey et al., this volume) has been used to define the base, e.g. in north Germany. The cement quarry near Erwitte, east Westfalia is particularly well suited to illustrate this event. Here the boundary approximates to the appearance of possible Forresteria petrocoriensis according to $\mathrm{E}$. Seibertz. $I$. deformis is widespread both in Europe and in North America.

c) In the well exposed and well investigated section of Salder in the Salzgitter area (see Bailey et al., this volume; Wood, Rasemann \& Ernst, this volume), the most characteristic event around the Coniacian boundary is a flood occurrence of Inoceramus (Cremnoceramus?) waltersdorfensis hannovrensis Heinz together with abundant Didymotis (D. costatus (Frič)?) in the upper Didymotis event (Wood, Rasemann \& Ernst, this volume). Elsewhere, (e.g. North and South America, Japan) the first occurrence of Didymotis is together with Lower Coniacian ammonites such as Forresteria, and inoceramids of the waltersdorfensis and rotundatus - erectus lineages.

In Salder it can be correlated with local echinoid biostratigraphy, but not with the international ammonite zonal scheme (Wood et al., this volume). In southern England early Coniacian inoceramids are found just above Forresteria petrocoriensis (see Bailey et al., this volume).

d) B. Pomerol suggested at the symposium that the appearance of Micraster decipiens (Bayle) should continue to define this boundary (= base of the Senonian) as is currently the practice in northern France and adjacent areas. This boundary is especially well exposed at St. Julien du Sault, Sens. Definition of this boundary on the basis of Micraster, either the entry of $M$. decipiens, or the entry of $M$. normanniae at the base of $M$. cortestudinarium Zone sensu Rowe is not recommended (see Bailey et al., this volume).

e) The nannofossil Marthasterites furcatus (Deflandre) is a world-wide marker, appearing at the base of the $M$. furcatus Zone, which is generally used by nannofossil specialists as the basal zone 
of the Coniacian. In England, however, and also in Germany, the first occurrence of this species lies well within the range and below the acmeoccurrence of Subprionocyclus neptuni, (Geinitz), an Upper Turonian index (see Bailey et al., this volume; Wood, Rasemann \& Ernst, this volume).

f) Marks (this volume) mentions that the appearance of Marginotruncana of the $M$. sinuosa group, together with the evolution of the $D i$ carinella primitiva - concavata group can be used provisionally to distinguish the Coniacian from the Turonian.

\section{Conclusion}

Boundary level: Definition of the boundary on the basis of first occurrence of Forresteria petrocoriensis, as proposed by Kennedy (this volume) gained most support. This level is widely recognizable, and close to the appearance of the important inoceramid species, I. walterdorfensis hannovrensis.

Boundary stratotype: In the Aquitaine basin including the type area - the boundary is marked by a discontinuity (see Kennedy, this volume), and stratigraphically important groups (e.g. inoceramids) are poorly represented or poorly investigated.

The Priesener Schichten in Czechoslovakia with a diverse ammonite and inoceramid fauna and a suitable facies for the preservation and extraction of micro- and nannofossils was considered most promising for the investigation of the boundary problem, and a re-study of this sequence was recommended.

El Kef in Tunisia, north Africa, was especially recommended with regard to micro- and nannofossils. (A number of localities in north Germany and north France were also considered, depending on the final decision on index species).

\section{Coniacian-Santonian Boundary}

\section{The Santonian Stage}

Author: Coquand (1857).

Type area: Environs of Saintes, Charente (see Séronie-Vivien, 1972, 1980; van Hinte 1979).

At Javrezac, one of the sections mentioned by Coquand as a type section for the Coniacian and
Santonian Stages, the boundary is drawn at a hardground between glauconitic limestones of the Coniacian below and marls of the Santonian above (see Kennedy, this volume).

Possible boundary levels

Ammonites

a) According to Grossouvre (1901) the 'Mortoniceras' ( $=$ Texanites) texanum Zone marks the base of the Santonian. However, T. texanum does not occur in the Aquitaine Basin - the type area - and there is no possibility of establishing an ammonite zonation of the Santonian in Aquitaine for the time being (see Kennedy, this volume). In spite of that, there is wide agreement among ammonite workers that the appearance of the subgenus Texanites (Texanites) is a good indicator of the Santonian boundary. It has been used in such widely scattered areas as Texas, Japan, southern Africa, Madagascar and the Middle East (see Kennedy, this volume) and Kennedy proposes in his paper the appearance of the subgenus as the marker for the boundary.

The appearance of the earliest Texanites, $T$. olivetti in Djebl Fguira Salah in Tunisia was proposed by some as the boundary level.

\section{Other groups}

b) The appearance of Inoceramus (Cladoceramus) undulatoplicatus has currently been used to define the boundary. It is widespread in $\mathrm{Eu}$ rope, USSR and North America, and owing to its characteristic form and sculpture is easy to determine.

In northern Germany it appears slightly later than Inoceramus of the pachti-cardissoides group, which in this area has been widely used as a boundary marker (Schulz, Ernst, Ernst \& Schmid, this volume).

c) The appearance of Inoceramus siccensis. This species is related to the Inoceramus (Platyceramus) cycloides group. It is known only from north Africa, where it occurs in great quantities together with rare Texanites at Djebl Fguira Salah, Tunisia.

\section{Conclusion}

Boundary level: The consensus at the symposium was that the first appearance of Texanites (Texanites) and of Inoceramus (Cladoceramus) undulatoplicatus are the two best boundary criteria. 
The two levels are not directly correlatable, but are probably not widely separated, and may in fact coincide (see Bailey et al., this volume). Further work on correlation of the appearance of these two species with other groups is still needed (see Bailey et al., this volume).

Boundary stratotype: The section at Djebl Fguira Salah, El Fahs, in Tunisia, with early representatives of Texanites (Texanites), is promising and should be further investigated.

If Inoceramus (Cladoceramus) undulatoplicatus should be chosen, possible boundary stratotypes are the coastal cliff-sections in Kent or Sussex, southern England (see Bailey et al., this volume); or Olazagutía quarry near Alsasua in Navarra, north Spain (Ernst, Wood \& Kannenberg, in prep.). In both places I. undulatoplicatus is abundant in two distinct closely-spaced beds in fossiliferous, apparently continuous sections.

\section{Santonian-Campanian Boundary}

\section{The Campanian Stage}

Author: Coquand (1857).

Type area: Grande et Petite Champagne, Falaises de la Gironde in northern Aquitaine (see Neumann 1980, van Hinte 1979, Séronie-Vivien 1972).

\section{Possible boundary levels}

\section{Ammonites}

Definition of the base of the Campanian on the basis of ammonites is problematic. Placenticeras bidorsatum, the index species of the oldest zone of the 'classic' zonation, is extremely rare in the type area. It appears to be restricted to northwest Europe, but is also rare in that area (see Kennedy, this volume).

Two other possibilities were discussed:

a) The evolution of Submortoniceras from Texanites is a good marker. Submortoniceras is known from Spain, Zululand, Madagascar, Mexico, The Gulf and Pacific coasts of the United States and British Colombia. It is not known from the type area of France.

Specifically, the appearance of Submortoniceras spathi was proposed. The species is known from North America, South Africa and Madagascar as well as from Spain. Chico Creek in California presents a good boundary section.

b) The Santonian-Campanian Scaphites hippocrepis lineage. The lineage is well dscribed from North America (Cobban 1969). Scaphites aquisgranensis (Schlüter, 1872), according to European authors, occurs together with Placenticeras bidorsatum and is regarded by Cobban as the latest of three distinct forms of $S$. hippocrepis ( $S$. hippocrepis III), which occur widely in the U.S. Western Interior, the Atlantic and Gulf Coast plains, the Aquitaine Basin, West Germany, Belgium and the Netherlands (Kennedy, this volume).

\section{Other groups}

c) The base of Gonioteuthis granulataquadrata of the $G$. granulata - quadrata lineage is widely used in West Germany for definition of the boundary.

The genus Gonioteuthis has a restricted Boreal distribution. However, detailed analysis of the Gonioteuthis lineage in the Santonian and Campanian of northern Germany has shown that the first appearance of G. granulataquadrata coincides with the extinction level of Marsupites testudinarius. This free living crinoid has a nearly global distribution and has currently been used as marker of the Santonian - Campanian boundary (Schulz et al., this volume).

If defined on the basis of the extinction of Marsupites alone, the coastal sections in Sussex would be ideally suitable as a candidate for the boundary stratotype, as the upper limit of Marsupites can be perhaps more clearly established here than in any other locality. Sussex, however, has the disadvantage that Gonioteuthis is extremely rare, and it is impossible to recognize the first appearance of $G$. granulataquadrata (Bailey et al., this volume). In the Lägerdorf section, northern Germany, where the extinction of Marsupites and the entry of $G$. granulataquadrata are coincident (Schulz et al., this volume), there is, however, sedimentary evidence of a regression/ non-sequence at the top of the Marsupites Zone. In the possibly more complete Sussex succession, Bailey et al. (this volume) show that the Marsupites Zone is followed by a thin zone of Uintacrinus anglicus at the top of which is found the entry of Bolivinoides culverensis, and that the latter serves as a practicable biostratigraphical datum.

Of interest may be the relationship between 
the boundary and the $33 / 34$ magnetic reversal (magneto-stratigraphic event) which may provide an isochronous datum at or near the biostratigraphical boundary.

d) The appearance of the coccolith Aspidolithus parcus Stradner (= Broinsonia parca Stradner) has currently been used by coccolith specialists for definition of the boundary. It is widely distributed (e.g. Europe, North Africa, cores from the Atlantic and Pacific) and its appearance in the Aquitaine Basin is at the Santonian-Campanian boundary in the traditional sense. It is well defined at Beaumont (Gironde Cliffs), Charente Maritime, southwest France according to M. Neumann. In southern England, however, it first appears in the Offaster pilula Zone (Bailey et al., this volume).

e) The first occurrence of the foraminifer Bolivinoides strigillatus (Chapman) was proposed, this being a very useful and widespread marker. However, in northern Germany, the first occurrence nearly coincides with the first occurrence at Lägerdorf of Marsupites testudinarius, index fossil of the Marsupites granulata Zone, conventionally referred to the Upper Santonian. In the Hannover area, $B$. strigillatus appears still earlier, near the base of the Uintacrinus socialis Zone (see Koch 1977), and it appears at approximately the same level in southern England (Bailey et al. 1983).

f) The appearance of Globotruncana arca Cushman has been used for a definition of the boundary, mainly in the Tethyan Realm. In Tunisia the first significant appearance of $G$. arca arca traditionally marks the base of the Campanian, and is here coincident with the first occurrence of Stensioeina labyrinthica (Cushman \& Dorsay) and Neoflabellina rugosa (d'Orbigny). The first occurrence of $N$. rugosa in northern Germany is close to the Santonian - Campanian boundary as defined on the basis of the appearance of $G$. granulataquadrata, and the boundary can thus be correlated with the Boreal Realm. It also coincides with the first occurrence of the coccolith Aspidolithus parcus (see d).

If defined on the basis of Tethyan foraminifera, Djebl Fguira Salah, El Fahs, Tunisia, would be a possible boundary section.

g) Marks (this volume) proposes to place the base at the extinction level of Dicarinella asymmetrica (Sigal, 1952). However, this species is of little value north of Tunisia, as it is probably highly depth/temperature controlled.

\section{Conclusion}

Boundary level: It was generally agreed that a boundary level close to the currently used appearance of Gonioteuthis granulataquadrata in the Boreal Realm would be desirable, as this boundary can be closely correlated with a number of other events, e.g. the extinction of Marsupites, extensively used for definition of the boundary. However, to use Gonioteuthis for the strict definition did not gain much support, partly because of its restricted Boreal occurrence, partly because the definition is dependent on detailed biometric analysis of large populations.

A definition on the basis of the coccolith Aspidolithus parcus was considered promising. However, the first appearance of this species is known to be diachronous. If defined on the basis of ammonites, a correlation with other biological events is crucial.

Boundary stratotype: Depending on the index species chosen, sections in north Germany, Charente, Sussex, Spain, North Africa or California may be considered.

\section{Campanian-Maastrichtian Boundary}

The Maastrichtian Stage

Author: Dumont 1849)

Type area: The Maastricht area, southeast Netherlands. A type section has been designated at the E.N.C.I. quarry in Limburg (see Felder, 1975). The type section includes only a part of the Upper Maastrichtian Substage as defined by Jeletzky (1951) and Surlyk (1970).

The boundary between Campanian and Maastrichtian as generally defined in north Europe is marked by a major hiatus in the type area (see Jeletzky 1951; Schmid 1959; Robaszynski et al. (in press); and Surlyk, this volume).

Possible boundary levels

Ammonites

There has been much disagreement on the Campanian-Maastrichtian boundary level. One widely used definition has been at the appearance of Hoploscaphites constrictus, and a definition 
around that level was recommended, but without consensus on the most appropriate index fossil.

a) Early occurrences of Hoploscaphites constrictus itself are extremely rare, and the species is almost restricted geographically to the European Boreal Realm. A definition on the basis of that species therefore was not considered useful.

b) Pachydiscus neubergicus has been used currently as index for the Lower Maastrichtian (see Wright in Arkell et al. 1957).

This species has the advantage of a wide distribution in Europe (both Boreal and Tethyan), North America and the Indo-Pacific Region and therefore was proposed for defining the boundary (see Kennedy, this volume).

European occurrences in north Germany, Denmark and Poland, however, are restricted to a level far above the appearance of Hoploscaphites constrictus - viz. around the boundary between the Lower and Upper Maastrichtian (as defined by Surlyk, 1970), and the occurrence at Neuberg, Austria, seems to belong to the same level, being associated with e.g. Hoploscaphites tenuistriatus (Kennedy, this volume).

It was recommended to investigate the stratigraphic distribution of Pachydiscus neubergicus in the ammonite-rich sections at Zumaya, Spain, a potential candidate for a boundary stratotype.

\section{Other groups}

c) The appearance of the belemnite Belemnella lanceolata (Schlotheim) has been widely used for definition of the boundary, first in Russia (Arkhangelsky 1912), subsequently in Boreal western Europe (Jeletzky 1951) (see Najdin 1979).

This boundary is close to the classical definition of the Maastrichtian on the basis of Hoploscaphites constrictus. Thus, in Kronsmoor, northern Germany, B. lanceolata appears $3.5-5 \mathrm{~m}$ below $H$. constrictus (see Schulz et al., this volume).

B. lanceolata is ideal as an index in Europe and USSR because of its common occurrence. Its appearance is well correlated with other macro- and microfossils in Kronsmoor (quarry Saturn) in northern Germany, a section therefore suitable as a boundary stratotype (proposed by Surlyk (1975, 1982) and Schulz (1978)). However, its restricted distribution - the Boreal Realm of Europe and USSR - is a serious disadvantage. d) Marks (this volume) emphasizes that the characteristic extinction event of the Tethyan planktonic foraminifer Globotruncanita calcarata seems to be close to the boundary level defined on the basis of ammonites, ranging to just above the lowest occurrence of Bostrychoceras polyplocum in north Africa, but there is no first-order correlation between ammonite or belemnite zonations and the calcarata Zone.

e) First occurrence of the planktonic foraminifer Globotruncana falsostuarti has been used to define the lowest zone of the Maastrichtian (G. falsostuarti Zone) in north Africa (see Salaj 1983): This level is, however, one foraminiferal Zone above the extinction level of $G$. calcarata and may thus indicate a level higher in the Maastrichtian (as usually defined).

The extinction of the widespread coccolith Quadrum trifidum has been used to define the base of the Maastrichtian. This event seems to mark a level well above the base of the Lower Maastrichtian.

\section{Conclusion}

Boundary level: It was widely accepted to keep the base of the Maastrichtian close to the appearance of Belemnella lanceolata, as this datum is so well defined and widely accepted in the Boreal Realm. However, there is a strong need for finer correlation of this boundary level with the succession in the Tethyan Realm possibly by planktonic foraminifera or coccoliths.

\section{Boundary stratotype:}

If Belemnella lanceolata is accepted as index, Kronsmoor in north Germany is excellently suited as a boundary-stratotype as already proposed (see above). In case other indices are chosen, Zumaya, North Spain, and El Kef, Tunisia, are possible candidates.

Acknowledgements. We are grateful to a great number of colleagues for comments and advice. In particular we thank Richard G. Bromley, Walter Kegel Christensen and Karen Nielsen for editorial and technical help.

\section{Dansk sammendrag}

I 1983 afholdtes et internationalt symposium om kridttidens etagegrænser i København. På baggrund af dette symposium diskuteres principper for grænsedragningen mellem kridttidens etager, og der gives en oversigt over forslag til fastlæggelse af de 
enkelte grænser. Disse forslag vil danne grundlag for de kommende års arbejde $\mathrm{i}$ "Subcommission on Cretaceous Stratigraphy".

\section{References}

Alcaydé, G. 1980: Le Turonien. In Les étages français et leurs stratotypes. Mém. B.R.G.M. 109, 139-144.

Allemann, F., Catalano, R., Farès, F. and Remane, J. 1971: Standard calpionellid zonation (Upper Tithonian-Valanginian) of the western Mediterranean Province. Proceed. II Plankt. Conf. Roma 1970, 2, 1337-1340.

Amedro, F. and Magniez-Jannin, F. 1982: Corrélations lithologiques et biostratigraphiques (ammonites, foraminifères) dans l'Albien du Boulonnais. Ann. Soc. géol. Nord. 101, 133-143.

Arkell, W. J., Furnish, W. M., Kummel, B., 'Miller, A. K., Moore, R. C., Schindewolf, O. H., Sylvester-Bradley, P. C. and Wright, C. W. 1957: Treatise on Invertebrate Paleontology, Pt. L, Mollusca 4, Cephalopoda, Ammonoidea (ed. by R. C. Moore). Kansas. $490 \mathrm{pp}$.

Arkhangelsky, A. D. 1912: The Upper Cretaceous deposits in the eastern part of European Russia. Materialy dlja geologii Rossii. 25.

Avram, E. 1983: Barremian ammonite zonation in the Carpathian area. Zitteliana 10, 509-514.

Bailey, H. W., Gale, A. S. Mortimore, R. N., Swiecicki, A. and Wood, C. J. 1983: The Coniacian-Maastrichtian Stages of the United Kingdom, with particular reference to southern England. Newsl. Stratigr. 12, $19-42$.

Bartenstein, H. 1977: Stratigraphic parallelism of the Lower Cretaceous in the northern hemisphere. News. Stratigr. 6, $30-41$.

Birkelund, T. and Håkansson, E. 1983: The Cretaceous of North Greenland - a stratigraphic and biogeographical analysis. Zitteliana 10, 7-25.

Breistroffer, M. 1947: Sur les Zones d'Ammonites dans d'Albien de France et d'Angleterre. Trav. Lab. Géol. Univ. Grenoble 26, 17-104.

Busnardo, R. 1965: Rapport sur l'étage Barrémien. Mém. Bur. Res. Géol. Minièr. 34, 161-169.

Busnardo, R., Thieuloy, J.-P. and Moullade, M. 1979: Hypostratotype mesogéen de l'étage Valanginien (sud-est de la France). Les stratotypes français $6,143 \mathrm{pp}$.

Callomon, J. H. and Donovan, D. T. 1966: Stratigraphic classification and terminology. Geol. Mag. 103, 97-99.

Callomon, J. H. and Donovan, D. T. 1974: A code of Mesozoic stratigraphical nomenclature. Colloque du Jurassique, Luxembourg, 1967. Mém. Bor. Rech. géol. minièr. 75 (for 1971), 75-81.

Caron, M. and Homewood, P. 1983: Evolution of early planktonic foraminifera. Marine Micropaleontology 7, 454-462.

Carter, D. J. and Hart, M. B. 1977: Aspects of mid-Cretaceous stratigraphical micropalaeontology. Bull. Br. Mus. nat. Hist. (Geol.) 29, 1-135.

Casey, R. 1954: New genera and subgenera of Lower Cretaceous ammonites. Jour. Washington Acad. Sci. 44, 106115.

Casey, R. 1960: A Monograph of the Ammonoidea of the Lower Greensand. Palaeontogr. Soc. (Monogr.) Pts I-IX, 1-660 (not yet completed).

Cobban, W. A. 1969: The late Cretaceous ammonites Scaphites leei Reeside and Scaphites hippocrepis (De Kay) in the Western Interior of the United States. Prof. Pap. U.S. geol. Surv. 619, 1-27.

Coquand, H. 1856: Notice sur la formation crétacée du département de la Charente. Bull. Soc. géol. France 2, 55-98.
Coquand, H. 1857: Position des Ostrea colomba et biauriculata dans le groupe de la craie inférieure. Bull. Soc. géol. France 2, 745-766.

Coquand, H. 1858: Description physique, géologique, paléontologique et minéralogique de Département de la Charente I. Besançon.

Coquand, H. 1861: Sur la convenance d'établir dans le groupe inférieur de la formation crétacée un nouvel étage entre le Néocomien proprement dit (couches à Toxaster complanatus et à Ostrea couloni) et le Néocomien Supérieur (étage Urgonien de d'Orbigny). Mém. Soc. Emul. Provence 1, 127-139.

Debelmas, J. and Thieuloy, J.-P. 1965. Étage Hauterivien. Mém. Bur. Res. Géol. Minièr. 34, 85-96.

Desor, E. 1854: Quelques mots sur l'étage inferieur du groupe néocomien (étage valanginien). Bull. Soc. Sci. nat. Neuchâtel 3, 172-180.

Desor, E. and Gressly, A. 1859: Études géologiques sur le Jura neuchâtelois. Mém. Soc. Sci. nat. Neuchâtel 4, 159 pp.

Destombes, P. 1979: Les Ammonites de l'Albien inférieur et moyen dans le stratotype de l'Albien: Gisements, Paléontologie, Biozonation. In L'Albien de l'Aube. Les stratotypes Français 5, 51-194. Éditions du CNRS.

Dubourdieu, G. 1956: Étude géologique de la région de l'Ouenza (confins Algéro-Tunisiennes). Bull. serv. Carte géol. Algér., n.s. 10,659 pp.

Felder, W. M. 1975: Lithostratigraphische Gliederung der oberen Kreide in Süd-Limburg (Niederlande) und den Nachbargebieten. Erster Teil: Der Raum westlich der Maas, Typusgebiet des "Maastricht". Publ. natuurhist. Genootschap Limburg, 24 (3-4), 43 pp.

Fletcher, B. N. 1973: The distribution of Lower Cretaceous (Berriasian-Barremian) Foraminifera in the Speeton Clay. In Casey, R, and Rawson, P. F. (eds): The Boreal Lower Cretaceous. Geol. J. Spec. Iss. 5, 161-168.

Grossouvre, A. de 1894: Recherches sur la craie supérieure, 2, Paléontologie. Les ammonites de la craie supérieure. Mém. Serv. Carte géol. dét. Fr., 264 pp.

Grossouvre, A. de 1901: Recherches sur la craie supérieure 1: Stratigraphie générale. Mém. Serv. Carte gél. det. Fr., 1013 $\mathrm{pp}$.

Hancock, J. M. 1960: Les ammonites du Cénomanien de la Sarthe. Compte-rendu soc. sav., Dijon 1959: Colloque sur le Crétacé supérieur français, 249-252.

Hart, M. B. 1973: Foraminiferal evidence for the age of the Cambridge Greensand. Proc. Geol. Ass. London 84, 65-82.

Hart, M. B. 1980: The recognition of Mid-Cretaceous sea-level changes by means of foraminifera. Cretaceous Research 1 , 289-297.

Hart, M. B., Bailey, H. W., Fletcher, B., Price, R. and Swiecicki, A. 1981: Cretaceous. In Jenkins, D. G. \& Murray, J. W. (eds): Stratigraphical Atlas of Fossil Foraminifera. British Micropalaeontological Soc., 149-227. Ellis Horwood Ltd.

Hart, M. B. and Bigg, P. J. 1981: Anoxic events in the Late Cretaceous Chalk Seas of North West Europe. In Neale, J. W. \& Brasier, M. (eds): The Micropalaeontology of Shelf Seas.

Hedberg, H. D. (ed.) 1976: International Subcommission on - Stratigraphic Classification: International Stratigraphic Guide. 200 pp. John Wiley and Sons, New York.

Hégarat, G. Le 1973: Le Berriasien du Sud-Est de la France. Doc. Lab. Géol. Fac. Sci. Lyon 43, 575 pp.

Hégarat, G. Le and Remane, J. 1968: Tithonique supérieur et Berriasien de la bordure cévenole. Correlation des ammonites et des calpionelles. Geobios 1, 7-70.

Hinte, J. E. van 1979: The Coniacian, Santonian and Campanian stratotypes. Lethaia 12, 183-187. 
Hoedemaeker, Ph. J. 1982: Ammonite biostratigraphy of the uppermost Tithonian, Berriasian and lower Valanginian along the Rio Argos (Caravaca, SE Spain). Scripta Geol. $65,81 \mathrm{pp}$.

Hoedemaeker, Ph. J. 1983: Reconsideration of the stratigraphic position of the boundary between the Berriasian and the Nemausian (= Valanginian sensu stricto). Zitteliana 10, 447-457.

Holland, C. H., Audley-Charles, M. G., Bassett, G., Cowie, J. W., Curry, D., Fitch, F. J., Hancock, J. M., House, M. R., Ingham, J. K., Kent, P. E., Morton, N., Ramsbottom, W. H. C., Rawson, P. F., Smith, D. B., Stubblefield, C. J., Torrens, H. S., Wallace, P. and Woodland, A. W. 1978: A guide to stratigraphical procedure. Geol. Soc. Lond. Spec. Rep. no. 10, 1-18.

Immel, H. 1978: Die Crioceratiten (Ancyloceratina, Ammonoidea) des Mediterranen und Borealen HauteriveBarreme (Unter Kreide). Palaeontographica. Abt. A, 163, 1-85.

Jarvis, J., Gale, A. S. and Clayton, C. 1982: Litho- and biostratigraphical observations on the type sections of the Craie de Villedieu Formation (Upper Cretaceous, western France). Newsl. Stratigr. 11, 64-82.

Jefferies, R. P. S. 1962: The Palaeoecology of the Actinocamax plenus Subzone (Lowest Turonian) in the Anglo-Paris Basin. Palaeontology 4, 609-647.

Jeletzky, J. A. 1951: Die Stratigraphie und Belemnitenfauna des Obercampan und Maastricht Westfalens, Nordwestdeutschlands und Dänemarks sowie einige allgemeine Gliederungs-Probleme der jüngeren borealen Oberkreide Eurasiens. Beih. Geol. Jb. 1, 142 pp.

Juignet, P. 1977: Ammonite faunas from the Cenomanian around Le Mans (Sarthe, France). Spec. Pap. palaeont. Soc. Japan 21, 143-150.

Juignet, P. 1980: Cénomanien. In Cavelier \& Roger (eds): Les étages français et leurs stratotypes. Mém. B.R.G.M., 109, 130-138.

Juignet, P., Damotte, R., Fauconier, D., Kennedy, w. J., Magniez-Jannin, F., Monciardini, C. and Odin, G. S. (in press): La limite Albien-Cénomanien dans la Sarthe. Étude des trois sondages dans la région type du Cénomanien. Bull. Bur. Rech. géol. min. Paris.

Kakabadze, M. 1983: On the Hauterivian-Barremian correlation between the South of the USSR and certain Southern and Northern regions of Europe. Zitteliana 10, 501-508.

Kauffman, E. G., Hattin, D. E. and Powell, J. D. 1977: Stratigraphic, paleontologic, and paleoenvironmental analysis of the Upper Cretaceous rocks of Cimarron County, northwestern Oklahoma. Geol. Soc. Amer. Mem. 149, 150 pp.

Kemper, E., Rawson, P. F. and Thieuloy, J.-P. 1981: Ammonites of Tethyan ancestry in the early Lower Cretaceous of north-west Europe. Palaeontology 24, 251-311.

Koch, W. 1977: Stratigraphie der Oberkreide in Nordwestdeutschland (Pompeckjsche Scholle), Teil 2: Biostratigraphie in der Oberkreide und Taxonomie von Foraminiferen. Geol. Jb. A38, 11-123.

Lanphere, M. A. and Jones, D. L. 1978: Cretaceous time scale from North America. In Cohee, G. V., Glaessner, M. F. and Hedberg, H. D. (eds): Contributions to the geologic time scale. Am. Ass. Petr. Geol., Studies in Geology 6, 388 pp.

Magniez-Jannin, F. 1975: Les Foraminifères de l'Albien de l'Aube: paléontologie, stratigraphie, écologie. Cahiers Paléont, Ed. C.N.R.S. Paris, 351 pp.

Mancini, E. A. 1977: Depositional environment of the Grayson Formation (Upper Cretaceous) of Texas. Trans. Gulf Coast Ass. geol. Soc. 27, 334-351.

Mancini, E. A. 1979: Late Albian and Early Cenomanian Grayson ammonite biostratigraphy in north-central Texas. J. Paleont. 53, 1013-1022.
Moullade, M., Taxy, S. and Tronchetti, G. 1980: Aptien. Mém. B.R.G.M. 109, 112-115.

Memmi, L. 1981: Biostratigraphie du Crétacé inférieur de la Tunisie nord-orientale. Bull. Soc. géol. Fr. 7 (23), 175-183.

Naidin, D. P. 1979: Vergleichende Stratigraphie der Oberen Kreide der russischen Tafel und West-Europas. Aspekte der Kreide Europas. IUGS Series A, Nr. 6, 497-510. Stuttgart.

Neumann, M. 1980: Campanien. In Les étages français et leurs stratotypes. Mém. B.R.G.M. 109, 161-170.

North American Commission on Stratigraphical Nomenclature 1982: North American Stratigraphic Code. Am. Ass. Petr. Geol. Bull. 67, 841-875.

Odin, G. S. 1982: Numerical dating in stratigraphy. Vol. I, II. John Wiley and Sons Publ., Chichester, 1094 pp.

d'Orbigny, A. 1840: Paléontologie française. Terrains crétacés. 1. Céphalopodes. 662 pp. Paris.

d'Orbigny, A. 1840-43: Paléontologie française. Terrains crétacés. 2. Gastéropodes. 456 pp. Paris.

d'Orbigny, A. 1847: Paléontologie française. Terrains crétacés. 4. Brachiopodes. 390 pp. Paris.

Owen, H. G. 1971: Middle Albian stratigraphy in the AngloParis Basin. Bull. Mus. nat. Hist. (Geology) Suppl. 8,164 pp.

Owen, H. G. 1979: Ammonite zonal stratigraphy in the Albian of North Germany and its setting in the Hoplitinid Faunal Province. In Wiedmann, J. (ed.) Aspekte der Kreide Europas. I.U.G.S. Series A. 6, 563-588.

Perch-Nielsen, K. 1983: Recognition of Cretaceous Stage Boundaries by means of calcareous nannofossils. In Birkelund, T., Bromley, R., Christensen, W. K., Håkansson, E. and Surlyk, F. (eds): Abstracts. Cretaceous Stage Boundaries Symposium, Copenhagen, 152-156.

Rat, P. et al. 1979: L'Albien de l'Aube. Les stratotypes français 5. C.N.R.S., Paris.

Rawson, P. F. 1983: The Valanginian to Aptian stages - current definitions and outstanding problems. Zitteliana 10, 493500.

Renevier, E. 1874: Tableau des terrains sédimentaires. Bull. Soc. vaud. Sci. nat. 13, 218-252.

Robaszynski, F., coordinator, 1982: Le Turonien de la régiontype: Saumurois et Touraine. Stratigraphie, biozonations, sédimentologie. Bull. Centres Rech. Explor. Prod. Elf Aquitaine 6, 119-225.

Robaszynski, F., Alcaydé, G., Amédro, F., Badillet, G., Damotte, R., Foucher, J. C., Jardiné, S., Legoux, O., Manivit, H., Monciardini, E. and Sornay, J. 1983: L'étage Turonien dans sa région type "de Saumur à Montrichard", biostratigraphie, sédimentologie, coupures. Mem. Mus. natn. Hist. nat. Paris, Ser. C, 49, 15-28.

Robaszynski, F., Caron, M., Gonzales Donoso, J. M., Wonders, A. A. H. and European Working Group on Planktonic Foraminifera (in press): Atlas of Late Cretaceous Globotruncanids. Révue de Micropaléontologie.

Salaj, J. 1980: Microbiostratigraphie du Crétacé et du Paléogene de la Tunisie septentrionale et orientale (Hypostratotypes tunisiens). Inst. Géol. de Dinoýz Štúr. Bratislava. 238 pp.

Schlanger, S. O. and Jenkyns, H. C. 1976: Cretaceous anoxic events: causes and consequences. Geol. Mijnb. 55, 170184.

Schmid, F. 1959: La Définition des limites Santonien-Campanien et de Campanien inférieur-superieur en France et dans le Nord-Ouest de l'Allemagne. Congr. Soc. Savantes 84, 535-545. Paris.

Schulz, M.-G. 1978: Zur Litho- und Biostratigraphie des Obercampan-Untermaastricht von Lägerdorf und Kronsmoor (SW-Holstein). Newsl. Stratigr. 7, 73-89. 
Séronie-Vivien, M. 1972: Contribution à l'étude du Sénonien en Aquitaine septentrionale. Les stratotypes: Coniacien, Santonien, Campanien, Les stratotypes français 2, C.N.R.S., 195 pp. Paris.

Séronie-Vivien, M. 1980: Coniacien, Santonien. In Les étages français et leurs stratotypes. Mém. B.R.G.M. 109, 150160.

Surlyk, F. 1970: Die Stratigraphie des Maastricht von Dänemark und Norddeutschland aufgrund von Brachiopoden. Newsl. Stratigr. 1, 7-16.

Surlyk, F. 1975: Die Brachiopoden der Hemmoorer Schreibkreide. Paläont. Ges. 45, Jahresver. Kurzfassung der Vorträge. 1 p. Hannover.

Surlyk, F. 1982: Brachiopods from the Campanian-Maastrichtian boundary sequence, Kronsmoor (NW Germany). Geol. Jb. A61, 259-277.

Thieuloy, J.-P. 1977: La zone à Callidiscus du Valanginien supérieur vocontien (Sud-Est de la France). Lithostratigraphie, ammonite fauna, limite ValanginienHauterivien, corrélations. Géol. Alpine 53, 83-143.
Tröger, K.-A. 1981: Zu Problemen der Biostratigraphie der Inoceramen und der Untergliederung des Cenomans und Turons in Mittel- und Osteuropa. Newsl. Stratigr. 9, 139 156.

Vasícek, Z., Michalik, J. and Borza, K. 1983: To the "Neocomian" biostratigraphy in the Križna-Nappe of the Strážovské Vrchy Mountains (Northwestern Central Carpathians). Zitteliana 10, 467-483.

Young, K. 1957: Upper Albian (Cretaceous) Ammonoidea from Texas. J. Paleont. 31, 1-33.

Young, K. and Powell, J. D. 1978: Late Albian-Turonian correlations in Texas and Mexico. Ann. Mus. Hist. nat. Nice, $4,25,1-39$. 